\title{
Analysis Of Judge's Decision On Notary Tort In South Jakarta District Court (Case Study No. 124/PDT.G/2017/PN.Jkt.Sel)
}

\author{
Ma'ruf Akib ${ }^{1}$ and Amin Purnawan²
}

Abstract. The purpose of this research is 1) To know the Judges considerations in determining Notary Torts in South Jakarta District Court, 2) To determine the Decision Execution Judge Effects of Torts committed Notary in South Jakarta District Court. The method in this research is descriptive. This type of research is normative. The method used is qualitative analysis, namely data obtained through fieldwork and research literature then arranged systematically, and then analyzed qualitatively to achieve clarity issues to be discussed. The data is then analyzed using a theoretical and interpretive positive law which has been poured and then deductively conclude to address existing problems.

Based on the results of research that the judge in analyzing the case with No. 124/PDT.G/2017/PN.Jkt.Sel seen from the evidence presented as witnesses, documentary evidence, conjecture, confession or oath that is revealed in the trial are: Defendant 1 and Defendant V and co-Defendant 1 and Defendant II helped found guilty of Torts; Plaintiff is the legal owner of the disputed land Right No. 3747/Pondok Pinang, covering an area of 310 M.2, Pictures situation 24-0201994 date No. 1242/1994; Sale and Purchase Deed before a Notary Noor Kholid Adam, SH., MH between Andrei Widjaya with Ir. Sugandi, canceled Based on Law; Mortgage Ranked First No. 5204/2016 based APHT PPAT Noor Kholis Adam, SH., MH, registered in the name of Standard Chartered Bank with registered office in Branch Jakarta dated August 29, 2016 is the Disability Law, Illegal, not have binding legal force; As a result of the implementation of decisions of law in case No. 124 / PDT.G / 2017 / PN.Jak.Sel relating to tort which did by Notary is null and void, with all the legal consequences of Notary Deed and the Co-Defendants, namely: Sale and Purchase Deed No. 202/2016 dated May 23, 2016, made before PPAT Noor Kholis Adam, SH., MH; Property Ownership Deed of Credit Agreement (KPP) No. 872 / MRG / V / 16 dated May 23, 2016; Property Title Deed of Credit Agreement (KPP) No. 873 / MRG / V / 16 dated May 23, 2016; Power of Attorney Imposing Mortgage No. 203/2016 dated May 23, 2016 of Notary PPAT Noor Kholis Adam, SH., MH .; Power of Attorney to charge Encumbrance No. 256/2016 dated June 22, 2016, made before PPAT Noor Kholis Adam, SH., MH. Granting Mortgage Deed No. 301/2016 dated July 21, 2016, made before PPAT Noor Kholis Adam, SH., MH .; Owned right certificate No. 3747/Pondok Pinang Size 310 M.2, Pictures Situation No. 1242/1994 dated February 24, 1994 on behalf of Andrie Widjaya burdened security rights to Standard Chartered Bank. Keywords: Judge's Decision; Torts; Notary.

\section{Introduction}

Based on Act No. 2 of 2014 amendments to the Act No. 30 of 2004 concerning Notary in the State Gazette of the Republic of Indonesia (LNRI) 2004 No. 117, Supplement to the State Gazette of the Republic of Indonesia (TLNRI) No. 4432 Act No. 02 of 2014 on the Amendment of Act No. 30 of 2004 concerning notary (hereinafter referred to UUJN-P),

\footnotetext{
${ }^{1}$ Lecturer of Faculty of Law, Universitas Muhammadiyah Kendari, Sulawesi Tenggara e-mail: maeroef@gmail.com

${ }^{2}$ Faculty of Law Universitas Islam Sultan Agung
} 
Article 1 (1) which provides as follows notary is a public official who is authorized to make the deed authentic and have the other authorities referred to in the Act or by other laws. According to R. Soegondo Notodisoerjo, notaries are public officials openbare ambtenaren, because it is closely connected with the authority or primary duties and obligations that make the deeds authentic. ${ }^{3}$

Carry out the duties of office of a Notary must hold fast to the Code of Conduct is the guidance office Of Notary. Code, guidance, morals or decency guidelines for a particular profession or a list of obligations in running a profession drawn up by members of the profession itself and bind them in practice. Thus the Notary Code of Conduct is the guidance, counseling, morals or decency guidelines Notary well as private and public officials appointed by the government in order to provide services to the general public, especially in the field of deed. ${ }^{4}$

Torts or Onrechtmatuge daad, according to the provisions of Article 1365 Civil Code that "Any act against the law, which thereby cause harm to others, require a person who due to his fault causing the loss was to replace the loss."

Of the provisions of the article, clearly visible elements of tort are: ${ }^{5}$

- their deeds

- Such actions should be against the law

- There must be a mistake

- There must be losses

- The causal relationships between actions and loss

Tort can be found both in the realm of the Criminal Law (public) as well as in the realm of civil law (private). Many found that ensnare cases to the Court Notary ranging from civil cases and criminal cases as well as existing was sentenced the court. So in running his task can not be refused again, this time quite a lot of cases-criminal cases that occur due Notary unprofessional behavior and favor one party at the deed has made. The impact of the deeds of all these there are some Notaries who have been designated as suspects, defendants and convicted.

Based on the description in the above background, the purpose of this research is: To know and analyze the consideration of the judge to act against the law notary in South Jakarta District Court (Case Study No. 124 / PDT.G / 2017 / PN.Jkt.Sel), and to know how the legal consequences of the implementation of the verdict against tort Notary in South Jakarta District Court (Case Study No. 124 / PDT.G / 2017 / PN.Jkt. Sel)

\section{Research methods}

This research is a descriptive analysis. This type of research is normative. The method used is qualitative analysis, namely data obtained through fieldwork and research literature then arranged systematically, and then analyzed qualitatively to achieve clarity issues to be discussed. The data is then analyzed using a theoretical and interpretive positive law which has been poured and then deductively conclude to address existing problems. ${ }^{6}$

\footnotetext{
3 R. Soegondo Notodisoerjono, 1993, Hukum Notariat di Indonesia Suatu Penjelasan, Raja Grafindo Persada, Jakarta, p. 8.

4 Liliana Tedjosaputro, 1995, Etika Profesi Notaris Dalam Penegakan Hukum Pidana, Bigraf Publishing, Yogyakarta, p 29

5 Wawan Muhwan Hariri, 2011, Hukum Perikatan Dilengkapi Hukum Perikatan Dalam Islam, Pustaka Setia, Bandung, p 85

${ }^{6}$ Ibid, p.119
} 


\section{Result and Discussion}

The term "tort" in Dutch called the onrechtmatige daad. Actually, the term unlawful act is not the only term that can be taken as a translation of onrechtmatige daad, but there are still other terms, such as: ${ }^{7}$ Actions contrary to the law; Actions contrary to the principles of law; Unlawful act; Unlawful; Civil misappropriation.

Actually, all these terms are essentially derived from the provisions of Article 1365 of the Civil Code which says that every tort, that cause harm to others, require a person who due to his fault causing the loss was to replace the losses. Furthermore, according to Article 1366 of the Civil Code, every person is responsible not only for losses caused by the loss, but also for the harm caused to negligence or lack of diligence carefully. While pursuant to Article 1367 paragraph (1) of the Civil Code, a person is not only responsible for the harm caused his own actions, but also for any loss caused actions of people who become dependents or caused by the goods which are under its supervision. ${ }^{8}$

In the case to be filed on the basis of tort, be aware of the things that caused the unlawful act it. First of all, plaintiff should have the right base, to property, right to use, right to build, right to enjoy, and others. Rights that should be used freely by the user, it has been violated by the defendant, either by intentionally or unintentionally, thus causing losses to the plaintiff (Article 1365 and Article 366 BW). ${ }^{9}$

Act that violates, to be described, where the location of the offense (real), for example, control the land without the consent of the plaintiff as eligible. So, the key elements (absolute) to be met in the case of tort is an element of the right base, the element is no losses and an element of the actions of others, either in the form of the actions of others, whether in the form of acts or omissions (jurisprudence of the Supreme Court of the Republic of Indonesia, dated 25 March 1976 No. 1057 K / Sip / 1973 jo. on December 23, 1987 No. 842 K / Pdt / 1986, which specifies that for the tort should prove their losses). ${ }^{10}$

The provisions of Article 1365 Civil Code, it can be known that an unlawful act will be prosecuted indemnity if it fulfills the following elements: ${ }^{11}$ The act should be against the law; The act should result in losses; The act should be done with an error; The act must be a causal relationship (causal).

In Article 1 point 1 UUJN, defined as a notary public official authorized to make an authentic deed and other authorities referred to in UUJN. The authority of notary, according to Article 15 UUJN is made the authentic act of the deeds, agreements and statutes that are required by legislation and / or desired by the stakeholders to be stated in an authentic deed, guaranteeing the creation date of the deed, saving certificates, giving grosse, copy, and official copies, all of it throughout the making of the deed it not also be assigned or excluded to other officials or others established by law. Similarly notary has authority to: ${ }^{12}$

- Certify the signatures and set a firm date in the letter under the hand by enrolling in special books;

\footnotetext{
7 P.N.H. Simanjuntak, 2015, Hukum Perdata Indoneia Edisi Pertama, Prenadamedia Group, Jakarta, p 303

8 Ibid, p 304

${ }^{9}$ Sophar maru hutagalung, Praktik Peradilan Perdata Dan Alternative Penyelesaian Sengketa, Sinar Grafika, Jakarta, p 114

${ }_{10}$ Ibid, p 115

${ }^{11}$ PNH Simanjuntak, loc. cit.

${ }^{12}$ Ibid, p. 16
} 
- Posted a letter the letter under the hand by enrolling in special books;

- Make copies of the original letters under the hands of the copy that contains a description as written and illustrated in the letter in question;

- Approve their compatibility with a photocopy of the original letter;

- Providing legal counseling in connection with the deed;

- A deed relating to land; or

- Creating a treatise deed auction.

If it is said Notary committed tort those who feel aggrieved should proofing. And if it says acted against the law it must meet the elements in accordance with Article 1365 of the Civil Code. In case, if the authentic act in question then remains standing Notary not as a party or participating perform or assist the parties in qualifying co-Defendants. If a notarial deed made problem by one of the parties who feel aggrieved of the deed made by Notary, then the party who feels aggrieved can file a claim form for compensation to the Notary is concerned, the obligation of the plaintiff, that the lawsuit must be proved that the loss was due directly from Deed. In both positions, from the aspect of outward, formal aspect and the aspect of material on Notary deed. ${ }^{13}$

In the case Decision No. 124 / PDT.G / 2014 / PN.Jkt.Sel said that the Defendant and CoDefendant (Notary) committed an unlawful act and declared null and void, with all the legal consequences on the Deed of Sale and Purchase made by PPAT / Notary Noor Kholis Adam, $\mathrm{SH} ., \mathrm{MH}$.

In consideration, the South Jakarta District Court judge found against the deed. Article 1365 of the Civil Code that a person can be said to carry out acts against the law if it meets the elements of which are:

- The act should be against the law; Notarial deeds done simply recorded what was described Defendant with the letters there and put it in the form of a deed. This is in accordance with Article 1 UUJNmain task notary, decisive as berikutof Notary is a public official (openbaar ambtenaar) are only authorized to make the deeds of all actions, agreements and decisions by general legislation may be required, or the or she is declared an authentic letter.

- The act should be done with an error; In the context of a deed. Defendant had never come before Notary. But the Notary staff who is under his supervision to shift the place of manufacture without notice Plaintiff Deed;

- The act must be a causal relationship (causal); Losses suffered by the plaintiffs as a result of an unlawful act committed Defendants and Co-Defendants. If the Defendant does not do it certainly would not occur losses to be borne by the plaintiff;

The ruling of the judge on an unlawful act committed by a notary in South Jakarta District Court (Case Study No. 124 / PDT.G / 2017 / PN Jkt.Sel) are:

PASSING

I. Granting Lawsuit Plaintiffs in part;

II. Defendant states I to V Defendant and Co-Defendant I and Co-Defendant II has committed an unlawful act;

III. Stating Sale and Purchase Agreements were made before the Notary Noor Kholis Adam, SH., MH. between Andrei Widjaya / Andrie Widjaya with Ir. Sugandi null and void;

IV. Plaintiff is the owner Sah states over disputed land Right No.3747 / Pondok Pinang, covering an area of 310 M.2, Pictures situation dated 24-02-1994 No.1242 / 1994

V. Stating Mortgage Ranked First No. 5204/2016 based APHT PPAT Noor Kholis Adam,

${ }^{13}$ Ibid, p 129 
$\mathrm{SH} ., \mathrm{MH}$. recorded on behalf of Standard Chartered Bank through its branch office in Jakarta registered dated August 29, 2016 is unlawful, invalid, does not have binding legal force;

VI. Also to punish the Defendant I and Co-Defendant II to abide by and adhere to this decision;

VII. Punish the Defendants to pay court costs incurred in this case amounted to Rp. 11.041 million (eleven million forty-one thousand rupiah);

VIII. Plaintiff refused to apart and rest;

In the matter of cancellation of the deed must be through a lawsuit in court. In contract law no legal consequences if certain subjective requirements and requirement filled. If objective not subjective requirement is not met, then the agreement can be canceled long as there is demand by certain people or stakeholders. This subjective requirement is always overshadowed by the threat of withdrawal by the parties concerned of their parents, guardians or supervisor. In order for a threat like that does not happen, then it may be requested confirmation of those concerned, that the agreement will remain in effect and binding on the parties. If the objective conditions are not met, the agreement is null and void, without any request from the parties, thus the agreement has never been considered and is not binding on anyone. Absolute void the agreement may also occur, if an agreement is made not met, but the rule of law has stated for legal actions must be made in a way that has been determined or contrary to morality or public order.

As a result of the implementation of decisions of law in case No. 124/PDT.G/2017/ PN.Jak.Sel associated with Torts committed by the notary is null and void, with all the legal consequences of Notary Deed or Co-Defendants, namely:

Nullification or cancellation of notarial deed stipulated in Article 84 UUJN. If the Notaries explicitly violate certain articles which directly confirms the violation, then the deed including having the strength of evidence as the deed under the hand. If not mentioned explicitly in the other chapters in accordance with Article 84 UUJN, then included in the deed null and void. The term nullification and cancellation no definite application, as described by Herlien Budiono. ${ }^{14}$ Then the Act came to reveal the lack of legal consequences, it is expressed by the simple term "void", but sometimes uses the term "null and pricing" (Article 879 of the Civil Code) or "no power" (Article 1335 of the Civil Code)

\section{Closing}

\subsection{Conclusion}

Based on the arguments which have been put forward in the previous chapter, it can take several conclusions as follows:

- Analysis of the law against the judge's decision on an unlawful act committed by a notary in South Jakarta District Court. The judge in analyzing the case with No. 124 /PDT.G/2017/PN.Jkt.Sel seen from the evidence presented as witnesses, documentary evidence, conjecture, confession or oath that is revealed in the trial are: Defendant 1 and Defendant V and Co-Defendant 1 and Defendant II Also convicted of Torts; Plaintiff is the legal owner of the disputed land Right No. 3747 / Pondok Pinang, covering an area of 310 M.2, Pictures situation 24-0201994 date No. 1242/1994; Sale and Purchase Deed before a Notary Noor Kholid Adam, SH., MH between Andrei Widjaya with Ir.

${ }^{14}$ Herlien Budiono, 2007, Kumpulan Tulisan Hukum Perdata di Bidang Kenotariatan, PT. Citra Aditya Bakti, Bandung, p 364. 
Sugandi, canceled Based on Law; Mortgage Ranked First No. 5204/2016 based APHT PPAT Noor Kholis Adam, SH., MH, registered in the name of Standard Chartered Bank with registered office in Jakarta Branch dated August 29, 2016 is the Disability Law, Illegal, not have binding legal force.

- As a result of the implementation of decisions of law in case No. 124/PDT.G/2017/ PN.Jak.Sel relating to tort which did by Notary is null and void, with all the legal consequences of Notary Deed and the Co-Defendants, namely: Sale and Purchase Deed No. 202/2016 dated May 23, 2016, made before PPAT Noor Kholis Adam, SH., MH; Property Ownership Deed of Credit Agreement (KPP) No. 872 / MRG / V / 16 dated May 23, 2016; Property Title Deed of Credit Agreement (KPP) No. 873 / MRG / V / 16 dated May 23, 2016; Power of Attorney Imposing Mortgage No. 203/2016 dated May 23, 2016 of Notary PPAT Noor Kholis Adam, SH., MH .; Power of Attorney to charge Encumbrance No. 256/2016 dated June 22, 2016, made before PPAT Noor Kholis Adam, SH., MH.; Granting Mortgage Deed No. 301/2016 dated July 21, 2016, made before PPAT Noor Kholis Adam, SH., MH .; Owned right certificate No. 3747 / Pondok Pinang Size 310 M.2, Pictures Situation No. 1242/1994 dated February 24, 1994 on behalf of Andrei Widjaya burdened security rights to Standard Chartered Bank;

\subsection{Suggestion}

- Expected Notaries in performing his respective duties more carefully and closely related in legal acts.

- Notaries do not necessarily want and follow the wishes of the parties in making the deed notarized.

- Notaries are expected to uphold the code of professional conduct in his post in order to avoid violations that could harm the Notary itself.

\section{Bibliography}

\section{Books}

[1] R. Soegondo Notodisoerjono, 1993, Hukum Notariat di Indonesia Suatu Penjelasan, Raja Grafindo Persada, Jakarta.

[2] Liliana Tedjosaputro, 1995, Etika Profesi Notaris Dalam Penegakan Hukum Pidana, Bigraf Publishing, Yogyakarta

[3] Wawan Muhwan Hariri, 2011, Hukum Perikatan Dilengkapi Hukum Perikatan Dalam Islam, Pustaka Setia,Bandung

[4] P.N.H. Simanjuntak, 2015, Hukum Perdata Indoneia Edisi Pertama, Prenadamedia Group, Jakarta

[5] Sophar Maru Hutagalung, 2012, Praktik Peradilan Perdata Dan Alternative Penyelesaian Sengketa, Sinar Grafika, Jakarta

[6] Herlien Budiono, 2007, Kumpulan Tulisan Hukum Perdata di Bidang Kenotariatan, PT. Citra Aditya Bakti, Bandung

\section{Legislation}

[1] Code of Civil law

[2] Act No. 12 of 2014 Concerning the Rules Notary

[3] The jurisprudence of the Supreme Court, dated March 25, 1976 Number 1057K / Sip / 1973 Jo. Date December 23, 1987 No. 842 K / Pdt / 1986

[4] Court's Decision No. 377 / PDT.G / 2014 / PN SMG 